\title{
Chronic progressive sinusitis unresponsive to conservative treatment
}

Pakanit Kittipinyovatha, Chusana Suankratay ${ }^{\mathrm{a}}$, Wanla Kulwichit ${ }^{\mathrm{a}}$, Noppacharn Uaprasert ${ }^{\mathrm{a}}$, Nattachai Srisawat ${ }^{\mathrm{a}}$, Teerasak Phewplung ${ }^{\mathrm{b}}$, Pawinee Rerknimitrc, Talerngsak Kanjanabuch ${ }^{\mathrm{a}}$, Wipawee Kittikowit ${ }^{\mathrm{d}}$, Thamathorn Assanasen ${ }^{\mathrm{d}}$

${ }^{a}$ Department of Medicine, ${ }^{b}$ Department of Radiology, ${ }^{c}$ Division of Dermatology, ${ }^{d}$ Department of Pathology, Faculty of Medicine, Chulalongkorn University, Bangkok 10330, Thailand

\author{
Discussants: \\ Pakanit Kittipinyovath (PK) (Internist), \\ Nattachai Srisawat (NS) (Nephrologist), \\ Teerasak Phewplung (TP) (Radiologist), \\ Talerngsak Kanjanabuch (TK) (Nephrologist), \\ Pawinee Rerknimitr (PR) (Dermatologist), \\ Wipawee Kittikowit (WK) (Pathologist), \\ Thamathorn Assanasen (TA) (Pathologist), \\ Noppacharn Uaprasert (NU) (Hematologist).
}

Case 1-2013: a 30-year-old man with chronic rhino-sino-orbital infiltration and nephritic/ nephrotic syndrome

PK (Internist): A 30-year-old-man was admitted to our hospital because of fever and fatigue for 2 weeks. The patient had been well until 2.5 years earlier, when tinnitus developed in his right ear accompanied by painless right cheek swelling. One week later, the swelling had progressed to the right periorbital area. Computed tomography (CT) of the paranasal sinuses revealed an ill-defined enhancing soft tissue lesion involving right upper and lower lids, cheek, and medial inferior intra-extraconal fat in the orbit. In addition, there were mucosal thickening in his right ethmoid sinus, bilateral maxillary sinuses, and right sphenoid sinus. A diagnosis of chronic rhinosinusitis with right periorbital cellulitis was made, and intravenous ceftriaxone and clindamycin were administered. Two weeks after hospitalization, repeated CT of paranasal sinuses showed no significant change. Endoscopic sinus surgery revealed mucosal thickening of both ethmoid and sphenoid sinuses and a right nasal polyp.

Correspondence to: Chusana Suankratay, M.D., Ph.D., Faculty of Medicine, Chulalongkorn University, Bangkok 10330, Thailand; csuankratay@gmail.com
The pathology of the nasal polyp showed chronic sinusitis with mild infiltration of eosinophils. Triamcinolone nasal spray was administered, but he still had intermittent fullness of right nostril, greenish discharge, and swelling of the right cheek with no fever.

One year prior to admission (PTA), the patient developed a generalized erythematous maculopapular rash on his face, arms, legs, and trunk, followed by intermittent generalized pitting pedal edema and foamy urine. Three months later, the patient was admitted to our hospital. On examination, the patient was chronically ill with a weight of $55.5 \mathrm{~kg}$, a blood pressure 153/83 mm Hg, a pulse rate 97 beats per minute, a temperature $37.5^{\circ} \mathrm{C}$, and a respiratory rate of 20 breaths per minute. There was right cheek swelling in accompanied by multiple palpable purpurea and livedo reticularis at both arms and legs with bilateral cervical lymphadenopathy, $0.5-0.8 \mathrm{~cm}$ in size. A blood and urine test were done. Complete blood count (CBC) revealed hemoglobin $(\mathrm{Hb})$ of $11.1 \mathrm{~g} / \mathrm{dL}$, hematocrit (Hct) of 34.4\%, white blood cell (WBC) of 5550/ $\mu \mathrm{L}$ [neutrophil (N) 51\%, lymphocyte (L) 41.3\%], platelet of $242,000 / \mu \mathrm{L}$. Blood urea nitrogen was $19 \mathrm{mg} / \mathrm{dL}$, creatinine $1.5 \mathrm{mg} / \mathrm{dL}$. Liver function test (LFT) showed total bilirubin (TB) of $0.33 \mathrm{mg} / \mathrm{dL}$, direct bilirubin (DB) $0.14 \mathrm{mg} / \mathrm{dL}$, alkaline phosphatase (AP) $213 \mathrm{U} / \mathrm{L}$, aspartate transaminase (AST) $50 \mathrm{U} / \mathrm{L}$, alanine aminotransferase (ALT) $41 \mathrm{U} / \mathrm{L}$, albumin 3.6 $\mathrm{g} / \mathrm{dL}$. Urinalysis (UA) revealed specific gravity of 1.009, pH 5.0, marked protein, moderate blood, WBC 10-20/high power field (HPF), red blood cells (RBC) 50-100/HPF, WBC casts $0-1 / \mathrm{HPF}$, fine granular casts $1-2 / \mathrm{HPF}$, coarse granular casts $1-2 / \mathrm{HPF}$. The 24hour urine protein was $3272 \mathrm{~g}$, urine $\mathrm{Cr} 42.3 \mathrm{mg} / \mathrm{dL}$, volume $1940 \mathrm{~mL}$, and estimated glomerular filtration rate (eGFR) $37.9 \mathrm{~mL} / \mathrm{min}$. Serum anti-HIV, anti-HCV, HBsAg were nonreactive, and anti-HBc and anti-HBs 
was positive (17.8 mIU/mL). Blood complement 3 (C3) level was $98.3 \mathrm{mg} / \mathrm{dL}$ (normal range 76-171), complement (C4) level $38.5 \mathrm{mg} / \mathrm{dL}$ (10-40), and total complement activity (CH50) $29.1 \mathrm{U} / \mathrm{mL}$ (19-40). Serum antinuclear antibody (ANA) was negative, rheumatoid factor $<10.1 \mathrm{IU} / \mathrm{mL}$, anti-cardiolipin IgG and $\operatorname{IgM}<12 \mathrm{U} / \mathrm{mL}$, cytoplasmic-antinuclear cytoplasmic antibody (c-ANCA) positive, perinuclearANCA (p-ANCA) negative, antimyeloperoxidase (anti-MPO) negative ( $<20$ ), antiproteinase3 (anti PR3) positive $52.9(<20)$, and cryoglobulin positive. Blood IgG1 was 1730 mg/dL (490-1140), IgG2 376 mg/dL (150-640), IgG3 204 mg/dL (20-110), IgG4 76.5 mg/ dL (8-140).

\section{Skin biopsy}

Skin lesion pathology revealed superficial and mid perivascular mixed inflammatory cell infiltrate comprising lymphocytes, histiocytes, neutrophils with few nuclear dusts, and extravasated red blood cells. There were also fibrinoid depositions around blood vessels. These findings were consistent with leukocytoclastic vasculitis.

\section{Sinuscopy}

There were a polypoid mass and purulent discharge at left middle meatus. In addition, there were thick mucoid discharges per right middle meatus and sphenoethmoidal recess.

\section{CT scan of the paranasal sinuses}

There was chronic right pansinusitis with inflammatory change involving soft tissue surrounding the right maxillary antrum and right orbit, extending to the right orbital apex. There was no visualized right middle turbinate and floor of right anterior ethmoid sinus, considered possibly postsurgical change.

\section{Biopsy of the polypoid mass at left middle meatus}

The pathology showed chronic inflammatory cell infiltrates and a tiny area of necrosis surrounded by epithelioid histiocytes. There were no organisms on acid fast and Grocott's methenamine silver (GMS) stains.

\section{Biopsy of the left maxillary sinus}

The pathology showed mixed necrotic fragments and viable tissues with edema and chronic inflammation. Eosinophils were occasionally seen.
Aggregation of epithelioid histiocytes was seen along subepithelium. There were no organisms on acid fast and GMS stains.

\section{Ultrasonography (USG) of the kidney urinary bladder (KUB) system}

A study revealed normal size and parenchymal echogenicity of both kidneys. The sizes of the right and left kidneys were about $11.2 \times 4.8 \mathrm{~cm}$, and $10.9 \times$ $5.6 \mathrm{~cm}$, respectively. There was no obstructive uropathy. The urinary bladder was well-distended with smooth outline and no abnormal internal echogenicity.

\section{Kidney needle biopsy}

Light microscopy revealed 30 glomeruli including one globally sclerosed glomerulus. All of the nonsclerosed glomeruli had moderate-to-marked increased mesangial cellularity. Three glomeruli had segmental sclerosing lesions involving the periphery with adhesion to Bowman's capsule. The glomerular capillary loops were not thickened. Four glomeruli showed accentuation of the lobulation together with segmental endocapillary proliferation with a few neutrophils in some capillary lumens. Five glomeruli contained cellular crescents, and two glomeruli contained fibrocellular crescents. There was patchy mild interstitial fibrosis and tubular atrophy in accompanying with moderate interstitial infiltrates of mononuclear inflammatory cells. The nonatrophic tubules had no remarkable changes. Some glomerular arterioles had thickened medial layer and no hyaline change. Fluorescence microscopy revealed 7 glomeruli showing mild linear IgG deposits along the glomerular basement membrane, moderate coarsely granular IgA deposits in the mesangium, negative IgM deposits, moderate coarsely granular $\mathrm{C} 3$ deposits in the mesangium, negative C1q deposits, trace coarsely granular kappa deposits in the mesangium, moderate coarsely granular lambda deposits in the mesangium, and mild coarsely fibrinogen deposits in the mesangium. The diagnosis was mesangial and focal segmental endocapillary proliferative glomerulonephritis with focal crescent formation.

The patient was with IgA nephropathy and systemic vasculitis, and received the treatment with oral cyclophosphamide and prednisolone. During the follow-up period, some clinical and nephrological data are shown in Table 1. 
Table 1. Clinical and nephrological data during the follow-up period of treatment with cyclophosphamide and prednisolone

\begin{tabular}{|c|c|c|c|c|c|c|c|c|}
\hline $\begin{array}{l}\text { Duration } \\
\text { of } R_{x} \\
\text { (PTA) }\end{array}$ & $\begin{array}{l}\text { Weight } \\
\text { (kg) }\end{array}$ & $\begin{array}{l}\text { Blood } \\
\text { pressure } \\
(\mathrm{mmHg})\end{array}$ & $\begin{array}{l}\text { BUN/Cr } \\
\text { (mg/dL) }\end{array}$ & Urine sp gr & $\begin{array}{l}\text { Sediment } \\
\text { (high power } \\
\text { field) }\end{array}$ & $\begin{array}{l}\text { 24-h } \\
\text { protein } \\
\text { (g) }\end{array}$ & UPCI & $\mathbf{R}_{\mathrm{x}}(\mathrm{mg} / \mathrm{d})$ \\
\hline $\begin{array}{l}2 \text { weeks } \\
\text { (14 mon.) }\end{array}$ & 62.2 & $137 / 92$ & 29/1.19 & 1.004 & $\begin{array}{l}\text { WBC 0-1, } \\
\text { RBC 20-30, } \\
\text { protein } 1+\end{array}$ & 1.77 & & $\begin{array}{l}\text { Cyclophosphamide } 100 \text { mg, } \\
\text { prednisolone } 50 \mathrm{mg} \text {, } \\
\text { enalapril }\end{array}$ \\
\hline $\begin{array}{l}4 \mathrm{~W} \\
(13 \mathrm{M})\end{array}$ & 66.2 & $130 / 75$ & 18/1.01 & 1.005 & $\begin{array}{l}\text { WBC } 0-1, \text { RBC } \\
5-10, \\
\text { protein } 3+\end{array}$ & 4.5 & 3.72 & $\begin{array}{l}\text { Cyclophosphamide } 100 \mathrm{mg} \text {, } \\
\text { prednisolone } 50 \mathrm{mg} \text {, } \\
\text { enalapril }\end{array}$ \\
\hline $\begin{array}{l}8 \mathrm{~W} \\
(12 \mathrm{M})\end{array}$ & 68.0 & $154 / 104$ & $16 / 1.21$ & 1.013 & $\begin{array}{l}\text { WBC 0-1, } \\
\text { RBC 3-5, } \\
\text { protein 3+ }\end{array}$ & & 2.83 & $\begin{array}{l}\text { Cyclophosphamide } 100 \mathrm{mg} \text {, } \\
\text { prednisolone } 30 \mathrm{mg} \text {, } \\
\text { enalapril }\end{array}$ \\
\hline $\begin{array}{l}12 \mathrm{~W} \\
(11 \mathrm{M})\end{array}$ & 69.7 & $150 / 93$ & 19/1.1 & $\begin{array}{l}1.012 \\
\text { Fine granular } \\
\text { cast } 0-1\end{array}$ & $\begin{array}{l}\text { WBC } 0-1, \\
\text { RBC } 1-2, \\
\text { protein } 3+, \\
\text { oval fat body } \\
0-1\end{array}$ & & 1.87 & $\begin{array}{l}\text { Cyclophosphamide } 100 \mathrm{mg} \text {, } \\
\text { prednisolone } 25 \mathrm{mg} \text {, } \\
\text { enalapril }\end{array}$ \\
\hline $\begin{array}{l}16 \mathrm{~W} \\
(10 \mathrm{M})\end{array}$ & 71.6 & $133 / 84$ & 14/1.12 & $\begin{array}{l}1.014 \\
\text { Fine granular } \\
\text { cast } 0-1\end{array}$ & $\begin{array}{l}\text { WBC } 0-1 \text {, } \\
\text { RBC 1-2, } \\
\text { protein 2+ }\end{array}$ & & 0.64 & $\begin{array}{l}\text { Cyclophosphamide } 75 \mathrm{mg} \text {, } \\
\text { prednisolone } 20 \mathrm{mg} \text {, } \\
\text { enalapril }\end{array}$ \\
\hline $\begin{array}{l}20 \mathrm{~W} \\
(9 \mathrm{M})\end{array}$ & 74.0 & $125 / 78$ & 17/1.02 & 1.010 & $\begin{array}{l}\text { WBC } 0-1 \text {, } \\
\text { RBC } 1-2 \text {, } \\
\text { protein } 1+\end{array}$ & & 0.56 & $\begin{array}{l}\text { Cyclophosphamide } 75 \mathrm{mg} \text {, } \\
\text { prednisolone } 15 \mathrm{mg} \text {, } \\
\text { enalapril }\end{array}$ \\
\hline $\begin{array}{l}24 \mathrm{~W} \\
(8 \mathrm{M})\end{array}$ & 73.4 & $145 / 79$ & 15/1.15 & 1.014 & $\begin{array}{l}\text { WBC } 0-1 \text {, } \\
\text { RBC } 0-1 \text {, } \\
\text { protein } 1+\end{array}$ & & 0.38 & $\begin{array}{l}\text { Cyclophosphamide } 75 \mathrm{mg} \text {, } \\
\text { prednisolone } 15 \mathrm{mg} \text {, } \\
\text { enalapril }\end{array}$ \\
\hline $\begin{array}{l}28 \mathrm{~W} \\
(7 \mathrm{M})\end{array}$ & 72.0 & $128 / 77$ & 17/1.18 & $\begin{array}{l}1.017 \\
\text { Fine granular } \\
\text { cast } 0-1\end{array}$ & $\begin{array}{l}\text { WBC } 0-1 \\
\text { RBC 1-2, } \\
\text { protein 2+ }\end{array}$ & & 0.47 & $\begin{array}{l}\text { Cyclophosphamide } 75 \text { mg, } \\
\text { prednisolone } 10 \mathrm{mg} \text {, } \\
\text { enalapril, losartan }\end{array}$ \\
\hline $\begin{array}{l}32 \mathrm{~W} \\
(6 \mathrm{M})\end{array}$ & 71.4 & $130 / 68$ & 17/1.12 & 1.013 & $\begin{array}{l}\text { WBC 0-1, } \\
\text { RBC 2-3, } \\
\text { protein trace }\end{array}$ & & 0.20 & $\begin{array}{l}\text { Cyclophosphamide } 50 \text { mg, } \\
\text { prednisolone } 5 \mathrm{mg} \text {, } \\
\text { enalapril, losartan }\end{array}$ \\
\hline $3 \mathrm{M}$ & 63.3 & $129 / 68$ & 16/1.13 & & - & & 0.35 & $\begin{array}{l}\text { Cyclophosphamide } 37.5 \mathrm{mg} \text {, } \\
\text { prednisolone } 5 \mathrm{mg}, \\
\text { enalapril, losartan }\end{array}$ \\
\hline
\end{tabular}

UPCI, urine protein creatinine index; sp gr, specific gravity; PTA, prior to admission; $\mathrm{M}$, month; W, week, $\mathrm{R}_{\mathrm{x}}$, treatment; BUN, blood urea nitrogen; Cr, creatinine; WBC, white blood cell; RBC, red blood cell; 1+ mild, 2+ moderate, 3+ moderate-tomarked, 4+ marked.

Three months PTA, he noted a few painless erythematous nodules, $5 \mathrm{~mm}$ in size, at medial side of his right thigh. The lesions slowly enlarged and coalescenced into a single $6 \mathrm{~cm}$ lesion, within a onemonth period. In addition, additional similar lesions developed at his left thigh, right wrist, trunk, face, and penis. He also had intermittent fever with chills and weight loss of $11 \mathrm{~kg}$.

The patient was an electrician who had no known underlying disease. He had smoked cigarettes for a decade and social alcohol drinking. He was a gay man who did not practice safe sexual activity.

On examination, the patient was alert and oriented with a Cushingoid appearance. His temperature was $39.0^{\circ} \mathrm{C}$, his blood pressure was 109/68 $\mathrm{mm} \mathrm{Hg}$, pulse rate was 100 beats per minute, and his respiratory rate 24 breaths per minute. There were a swelling of his right cheek and periorbital area. There were multiple erythematous papules, nodules, ulcers, and ulcerated masses varying in size from 1 to $6 \mathrm{~cm}$, on extremities, thighs, trunk, hard palate, pharynx, and penis; some were necrotic with crust covering (Figure 1). There were bilateral cervical and posterior auricular lymphadenopathy, $0.5-2 \mathrm{~cm}$ in diameter. There was mild pitting pedal edema. The abnormal neurological signs are limit EOM in adduction and upward gaze of the right eye. The remainder of the examination was normal. 


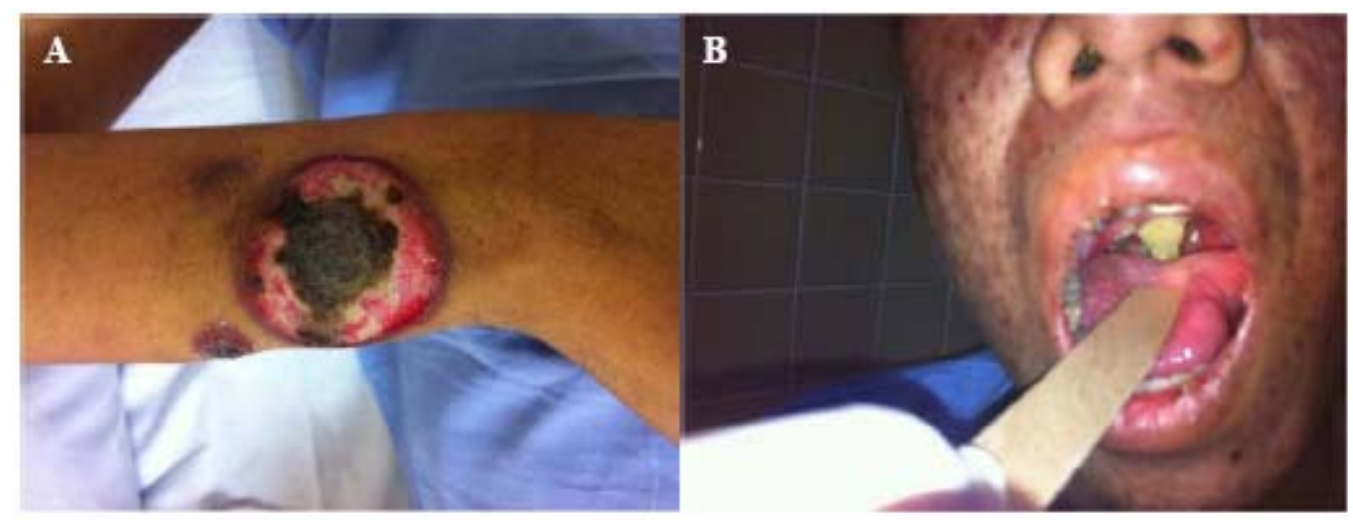

Figure 1. Panel A shows a big ulcerated mass with central necrosis at his left wrist. Panel B shows necrotic lesions at uvula and hard palate. (Clinical photographs with permission of the patient's nearest relatives.)

\section{Laboratory investigations}

CBC revealed $\mathrm{Hb}$ of $10.8 \mathrm{~g} / \mathrm{dL}$, Hct 32.0\% (MCV 80.6 fL, RDW 14.4\%), WBC 4,110/ $\mu \mathrm{L}$ (N 90.3\%, L $6.3 \%$ ), platelet count $256,000 / \mu \mathrm{L}$. UA showed specific gravity of $1.010, \mathrm{pH} 5.0$, protein $1+$, negative glucose, moderate blood, RBC 0/HPF, WBC 0-1/HPF. Spot urine protein/urine creatinine ratio was 1.88 (protein $100.8 \mathrm{mg} / \mathrm{dL}$ creatinine $53.4 \mathrm{mg} / \mathrm{dL}$ ). 24-hour urine protein was $2010 \mathrm{mg}$, volume $2640 \mathrm{~mL}$, eGFR $52 \mathrm{~mL} /$ min. BUN was $33 \mathrm{mg} / \mathrm{dL}$, and creatinine was 1.47 $\mathrm{mg} / \mathrm{dL}$. Electrolytes revealed $\mathrm{Na}$ of $117 \mathrm{mmol} / \mathrm{L}$, $\mathrm{K} 4.6 \mathrm{mmol} / \mathrm{L}, \mathrm{Cl} 87 \mathrm{mmol} / \mathrm{L}, \mathrm{HCO} 313 \mathrm{mmol} / \mathrm{L}$. LFT showed TB of $0.59 \mathrm{mg} / \mathrm{dL}$, DB $0.32 \mathrm{mg} / \mathrm{dL}$, AST 56 U/L, ALT $28 \mathrm{U} / \mathrm{L}$, alkaline phosphatase $133 \mathrm{U} / \mathrm{L}$, protein $6.0 \mathrm{~g} / \mathrm{dL}$, albumin $3.1 \mathrm{~g} / \mathrm{dL}$. Blood lactate dehydrogenase (LDH) was $1513 \mathrm{U} / \mathrm{L}$, uric acid 5.5 $\mathrm{mg} / \mathrm{dL}$, creatine phosphokinase (CPK) $470 \mathrm{U} / \mathrm{L}$. Serum anti-HIV, HBsAg, and anti-HCV were negative, and anti-HBs was $10.5 \mathrm{mIU} / \mathrm{mL}$.

Serum VDRL was nonreactive. Blood C3 level was $89.7 \mathrm{mg} / \mathrm{dL}$ (normal range 76-171), C4 level 3.9 $\mathrm{mg} / \mathrm{dL}$ (10-40), CH50 35 U/mL (19-40). Blood ANA was 1: 80 with fine speckle type, anti-dsDNA and anti-Sm negative, p ANCA positive, c ANCA negative, anti-MPO negative, anti-PR3 weakly positive, cryoglobulin positive, and rheumatoid factor negative. Chest X-ray image was normal.

\section{Cranial magnetic resonance imaging (MRI)}

There was an increase in size of soft tissue mass involving the right orbit including orbital apex and right masticator space as well as evidence of bony erosion (Figure 2).

\section{Chest CT}

There were several small lymphadenopathy at the bilateral paratracheal, paraaortic, and subcarina areas. In addition, there were multiple small nodules with varying in size from 0.5 to $2.6 \mathrm{~cm}$, scattered in both lungs, more at bilateral upper lobes. There were a focal consolidation at lingular segment and bilateral pleural effusion, more on the left.

\section{Abdominal CT}

There were multiple small paraaortic and aortocaval lymphadenopathy and a moderate amount of ascites.

\section{Biopsy of paranasal sinuses}

Pathology of right middle turbinate revealed multiple areas of necrosis accompanied by infiltrations with mononuclear cells mixed with rare neutrophils. Neither granuloma nor vasculitis was observed. The pathology of the right nasal septum revealed moderate infiltrations comprising mainly neutrophils. Necrotic area, granuloma, and vasculitis were not observed. The pathology of the right inferior turbinate revealed fibrous tissue infiltrated with some lymphocytes. Granuloma and vasculitis were not present.

\section{Kidney biopsy}

Light microscopy revealed 14 glomeruli including 2 globally sclerosed glomeruli. All of the nonsclerosed glomeruli had mild widening of the mesangial area with mild increased cellularity. Four glomeruli had segmental adhesion to the Bowman's capsule. The glomerular capillary loops were not thickened. No endocapillary hypercellular was present. One glomerulus had periglomerular fibrosis. Two glomeruli 

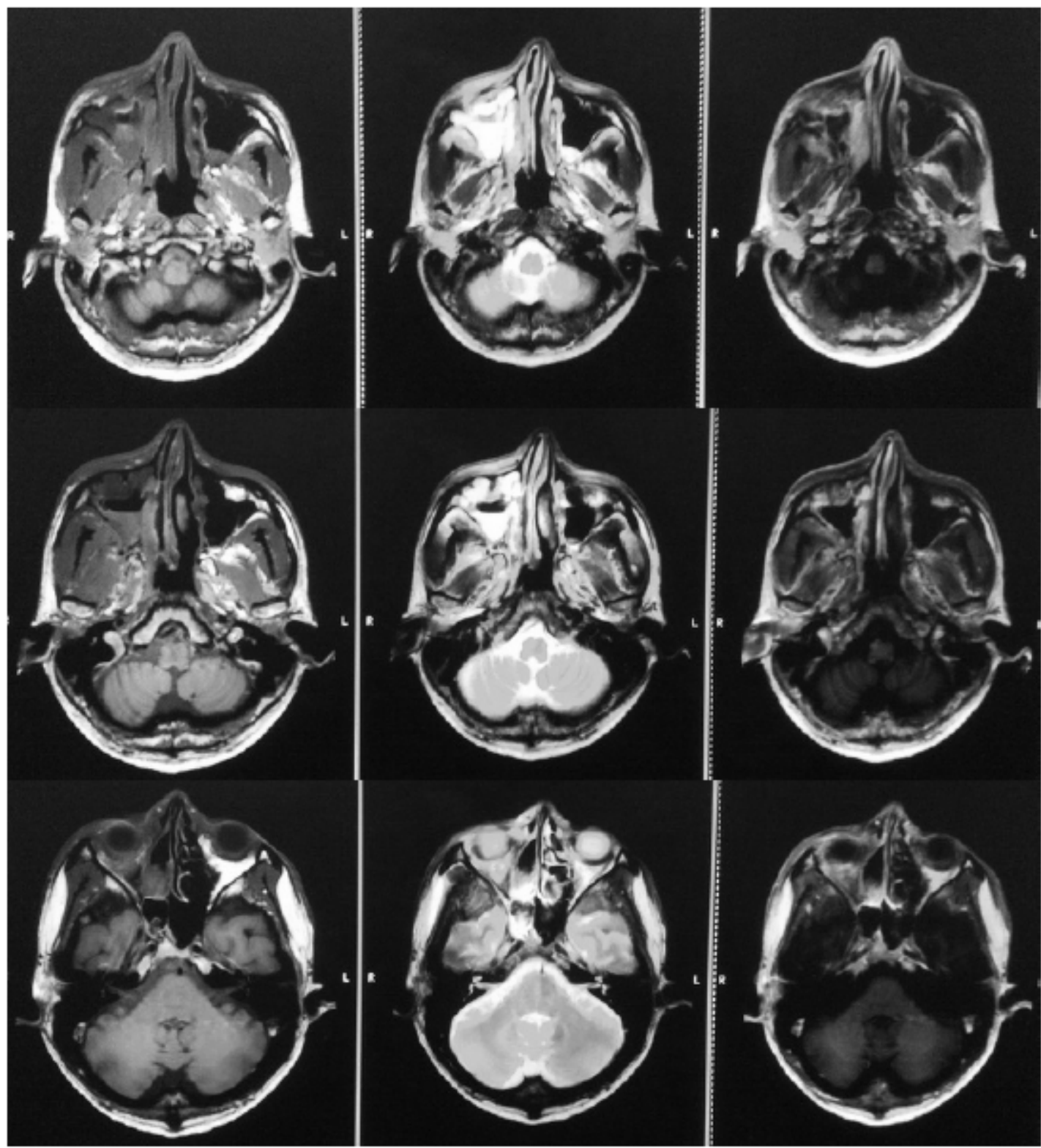

Figure 2. Cranial magnetic resonance imaging showing an increase in size of soft tissue mass involving right orbit including orbital apex and right masticator space as well as evidence of bony erosion.

contained fibrous crescents. There was patchy mild interstitial fibrosis and tubular atrophy in accompanying with mild interstitial infiltrate with mononuclear cells (approximately 25\% of the tissue). Some tubules had mildly flattened tubular epithelial cells. The glomerular arterioles were within normal appearance. Two interlobular arteries had no remarkable change. Fluorescent microscopy revealed 6 glomeruli showing negative IgG and IgM deposits, moderate coarsely granular IgA deposits in the mesangium, mild-tomoderate coarsely granular C3 deposits in the mesangium, negative C1q deposits, trace coarsely granular kappa deposits in the mesangium, mild-andmoderate coarsely granular lambda deposits in the mesangium, and mild coarsely granular fibrinogen deposits in the mesangium. The diagnosis was mild mesangial proliferative IgA nephropathy.

\section{Bone marrow aspiration}

The aspirate showed mild hypocellularity with myeloid to erythroid ratio of 2:1 and mild dysplasia of erythroid series. 


\section{Bone marrow biopsy}

The biopsy revealed moderate hypocellularity with myeloid to erythroid ratio of 2:1.

\section{Differential diagnosis}

NS (Nephrologist): The patient came with prolonged fever, chronic rhinosinusitis, and nephritic/nephrotic syndrome. I will discuss the problems that bring him to the hospital at the first time. From all imagings, he had evidence of bony erosions of the bones of paranasal sinuses. It might be caused by any invasive disease. May we review the radiologic studies?

TP (Radiologist): The paranasal CT showed marked soft tissue thickening of right medial rectus muscle and periorbital soft tissue and haziness of intraconal fat with contrast enhancement, compatible with the inflammatory process. There was also chronic sinusitis of bilateral sphenoid, ethmoid, and maxillary sinuses. These findings of periorbital and intraconal inflammation as well as chronic sinusitis are common in patients with invasive fungal rhinosinusitis with malignant complications.

NS (Nephrologist): The differential diagnosis of chronic sinusitis includes [1]:

1. Anti-nuclear cytoplasmic antibody (ANCA) -associated vasculitis.

2. Chronic invasive rhino-sinus infection from Mycobacterium or filamentous molds [2].

3. Malignancy.

4. Other processes including sarcoidosis, druginduced midline destructive lesion (cocaine).

The results of the biopsy specimens of the sinuses was compatible with lethal midline granuloma [1]. So, the differential diagnosis includes:

1. Neoplasm: non-Hodgkin lymphoma (NHL), skin cancer (squamous cell carcinoma, basal cell carcinoma).

2. Autoimmune disease: ANCA-associated vasculitis, Goodpasture's syndrome, $\mathrm{Sj}$ gren syndrome, systemic lupus erythematosus (SLE), and Beh et disease.

3. Infection: bacteria, Mycobacterium, filamentous mold, protozoa, spirochete.

4. Drug: cocaine induced lethal midline granuloma.

5. Other processes: chronic kidney disease, inflammatory bowel diseases (IBD).

6. Unknown cause: sarcoidosis, eosinophilic granuloma, idiopathic midline destructive disease.
This patient also had prolonged fever, marked weight loss, generalized edema, and foamy urine that may help to narrow down the differential list of diagnosis that includes malignancy, chronic infection, and autoimmune disease. He should undergo rebiopsy from multiple sites of paranasal sinuses.

The laboratory investigations suggest nephritic/ nephrotic urine pattern with normal complement level and positive serum cryoglobulin and c-ANCA. So, the differential diagnosis includes both immune complex and pauci-immune glomerulonephritis. Based on the results of first kidney biopsy, which showed mesangial proliferation, segmental endocapillary proliferation and $23 \%$ crescentic glomeruli with moderate IgA, C3, and lambda deposition in the mesangium, a diagnosis of primary IgA nephropathy is appropriate. There are a wide range of severity of primary IgA nephropathy from asymptomatic hematuria to rapidly progressive glomerulonephritis (RPGN) [3]. However, primary IgA nephropathy cannot explain all systemic symptoms including rhino-sino-orbital infiltration, skin lesions, fever, and marked weight loss in our patient.

This patient had a history of chronic nasal infection that may activate the hyperactivity of local immune system. Therefore, it can stimulate the production of secretory IgA, which is then absorbed into systemic circulation, causing IgA deposition in the kidneys. If this is the case, this condition should respond very well to the treatment with cyclophosphamide and high doses corticosteroid for 1 year.

During the current admission, he presented with multiple large ulcers on his trunk, legs, pharynx, and genitalia with associated constitutional symptoms. On examination, there were bilateral cervical and posterior auricular lymphadenopathy and multiple ulcers at hard palate, posterior pharynx, and uvula. I think these lesions are compatible with pyoderma gangrenosum (PG)-liked lesions. There are 4 variants of PG including (a) ulcerative lesions: the association includes autoimmune disease, hematologic malignancy, and IBD, (b) vesicobullous lesions: the association includes autoimmune disease, hematologic malignancy, and IBD, (c) pustular lesions: the association includes IBD, and (d) vegetative lesions: the association includes chronic kidney disease [4]. The causes of PG includes vascular occlusive diseases (e.g. antiphospholipid syndrome), vasculitis (e.g. Wegener granulomatosis, polyarteritis nodosa, or cryoglobulinemia), cutaneous involvement of malignant process (e.g. lymphoma, leukemic cutis, Langerhans-cell histiocytosis), primary 
cutaneous infection (e.g. deep fungal infection), druginduced PG, and other processes (e.g. IBD).

Serum cryoglobulin, p-ANCA, and anti-PR3 were positive. Some patients with crescentic primary IgA nephropathy can have positive ANCA, and its levels correlate with the disease severity [3]. The pathology of the second kidney biopsy showed marked improvement after the treatment with immunomodulators.

TP (Radiologist): The cranial MRI showed the signs of chronic sinusitis at right maxillary and ethmoid sinus with intraconal fat involvement, but without intracranial and nasal septum involvement. The chest $\mathrm{X}$-ray image showed a mass-liked consolidate lesion at left middle lung zone with pleural effusion and multiple pulmonary nodules at both lungs. Pulmonary metastasis might be the first differential diagnosis from these images.

NS (Nephrologist): Because of the slow progression of the disease during a 2.5-year period and some partial response to immunomodulators in kidney biopsy, chronic invasive fungal infection of the paranasal sinuses can be excluded. The patient finally developed PG-like lesions, multiple pleural and lung nodules, generalized intrathoracic, and intraabdominal lymphadenopathy. The differential diagnosis should be narrow to include hematologic malignancy including lymphoproliferative disorder, extranodal NK/T cell lymphoma, and diffuse large B-cell lymphoma. A previous study regarding extranodal malignant lymphoma at King Chulalongkorn Memorial Hospital showed that DLBCL was the most common lymphoma (66.7\%), followed by NK/T cell lymphoma (16.7\%) which mostly involved nasal and paranasal sinuses (84\%) and was frequently observed in male patients [5]. Some patients with malignant lymphoma can present with secondary IgA nephropathy [6], and some also have associated PG-liked lesions [7].

The most likely diagnosis in this patient should be the EBV-associated lymphoproliferative disorder, and further investigations should include (a) an immunohistochemical study and in situ hybridization assay for EBV-encoded RNA (EBER) from the biopsy tissues from paranasal sinuses or (b) rebiopsy under general anesthesia for more adequate tissue of paranasal sinuses. In addition, the skin biopsy should be performed to exclude malignant lymphoma as well.

PK (Internist): The pleural fluid study showed exudative profile with high LDH level and predominate mononuclear cells and some atypical medium-size lymphoid cells. Blood EBV viral load was 850,000 copies/mL. Serum anti-EBV viral capsid antigen (VCA) IgG was positive, anti-EBV IgM and antiEpstein-Barr virus nuclear antigen (EBNA) were negative.

TK (Nephrologist): The primary IgA nephropathy, the most common cause of glomerulopathy, can be a concomitant disease with other glomerular diseases in patients presenting with nephrotic, nephritic, and nephritic/nephrotic syndromes. In addition, there are also secondary IgA nephropathy. This patient had pyuria (which is rare in primary IgA nephropathy) and persistent proteinuria which the severity of the disease did not correlate well with the kidney biopsy results. Another clue for secondary cause of IgA nephropathy is the associated extrarenal symptoms and signs including chronic progressive sinusitis, skin lesions, and marked weight loss. If this patient has NK/T cell lymphoma associated with secondary IgA nephropathy, it will be the first case in our institution. The confirmation of secondary IgA nephropathy requires the characteristic findings by electron microscopy. Other possibility is that there may be a concomitant primary IgA nephropathy with malignant lymphoma.

PR (Dermatologist): The typical PG lesions should have undermined edge with overhanging epidermis and grey rim. The lesion needs further biopsy to confirm the diagnosis and associated condition.

WK (Pathologist): The first kidney biopsy showed few crescents, segmental endocapillary proliferations, moderate mesangial proliferations, and moderate mesangial IgA deposits, compatible with diffuse mesangial and focal endocapillary proliferative IgA nephropathy with few crescents. The second kidney biopsy showed improvement with mild mesangial proliferations. Further study for EBV, in situ hybridization assay for EBER gene was positive in the interstitium of the kidney.

TA (Pathologist): The skin biopsy from PG-like lesion showed some necrotic tissue with some areas of cell infiltration in the dermis and vessel walls. The cells were consistent with the medium-sized lymphoma cells. The immunohistochemistry study showed positive CD3, CD56, and cytotoxic molecules. The T- 
cell receptor gene rearrangement study showed the clonal rearrangement of beta and gamma chains of $\mathrm{T}$ cells. There was also a positive in situ hybridization assay for EBER gene. The definite diagnosis is extranodal EBV-associated NK/T cell lymphoma. The previous tissues from paranasal sinuses were re-evaluated and consistent with EBV-associated NK/T cell lymphoma as well.

NU (Hematologist): After the diagnosis, this patient had no response to first course of chemotherapy and eventually died. Thailand is an endemic area for EBVassociated NK/T cell lymphoma. We should have a high index of suspicion of this disease when caring for patients presenting with chronic progressive sinusitis with no response to conservative treatment.

\section{Ethical clearance}

The authors thank the nearest relatives of the patient for written informed consent allowing the case to be discussed, reviewed, and published. The Institutional Review Board of the Faculty of Medicine, Chulalongkorn University approved the retrospective review and discussion of patient records and publication of the manuscript.

\section{References}

1. Parker NP, Pearlman AN, Conley DB, Kern RC, Chandra RK. The dilemma of midline destructive lesions: a case series and diagnostic review. Am J Otolaryngol. 2010; 31:104-9.

2. Chakrabarti A, Denning DW, Ferguson BJ, Ponikau J, Buzina W, Kita H, et al. Fungal rhinosinusitis: a categorization and definitional schema addressing current controversies. Laryngoscope. 2009; 119: 1809-18.

3. Boyd JK, Cheung CK, Molyneux K, Feehally J, Barratt J. An update on the pathogenesis and treatment of IgA nephropathy. Kidney Int.2012; 81: 833-43.

4. Weenig RH, Davis MD, Dahl PR, Su WP. Skin ulcers misdiagnosed as pyoderma gangrenosum. $\mathrm{N}$ Engl $\mathrm{J}$ Med. 2002; 347:1412-8.

5. Assanasen T, Wannakrairot P, Keelawat S, Ruangvejvorachai P, Pramprayoon N. Extranodal malignant lymphoma of the upper aerodigestive tract: prevalence of Epstein-Barr virus infection in King Chulalongkorn Memorial Hospital. J Med Assoc Thai. 2005; 88 (Suppl 4):S266-73.

6. Wilson FP, Nasr SH, Markowitz GS, Naylor EC, Sterman PL, D’Agati VD. A destructive nasal lesion and glomerulonephritis. Kidney Int. 2006; 69:1699-703.

7. Emauel PO, Mercer SE. Angiocentric NK/T-cell lymphoma mimicking pyoderma gangrenosum. Indian J Cancer. 2011; 48:113-5. 